as having been caused by Professor Laflamme's communication to the geographical section of the British association at its late meeting in Montreal.

They commenced with a very sensational article in the Montreal witness dated Quebec, Nov. 17, arising out of an interview of a reporter with $\mathrm{Mr}$ F. H. Bignell, a gentleman who had just returned from a trip to the Hudson Bay post on Lake Mistassini, made for the purpose of taking in supplies for the winter consumption of the party organized and despatched last spring, by the geological survey, to explore that region, and to complete the survey of the lake, which was commenced in 1870 , and continued in 1871, as described in the report of the survey for those years, and of which surveys Professor Whitney does not appear to be cognizant, or of my letters to the editors of the Ottawa free press and the Montreal gazette of Nov. 17 and Nov. 25 respectively, in which the substance of the foregoing remarks was stated. assigned to it in the geological survey map of 1866 , while its outline is also very different. That it consists of several almost separate lakes, as described by the old explorers, is, I think, certain; but the assumption that there is a body of water in any way comparable to Lake Superior is exceedingly improbable, and not warranted by any recorded observations.

AlFRed R. C. SELWYN,

Director, geological survey of Canada.

\section{Lava from the new volcano on Bogosloff Island.}

Three specimens of the lava which was erupted from the new volcano on Bogosloff Island, Alaska, in October, 1883, were sent by Sergeant Applegate, the signal-service observer at Unalashka, to the central office in Washington, and referred to the U. S. geological survey for investigation.

It is gratifying to note that an examination of these

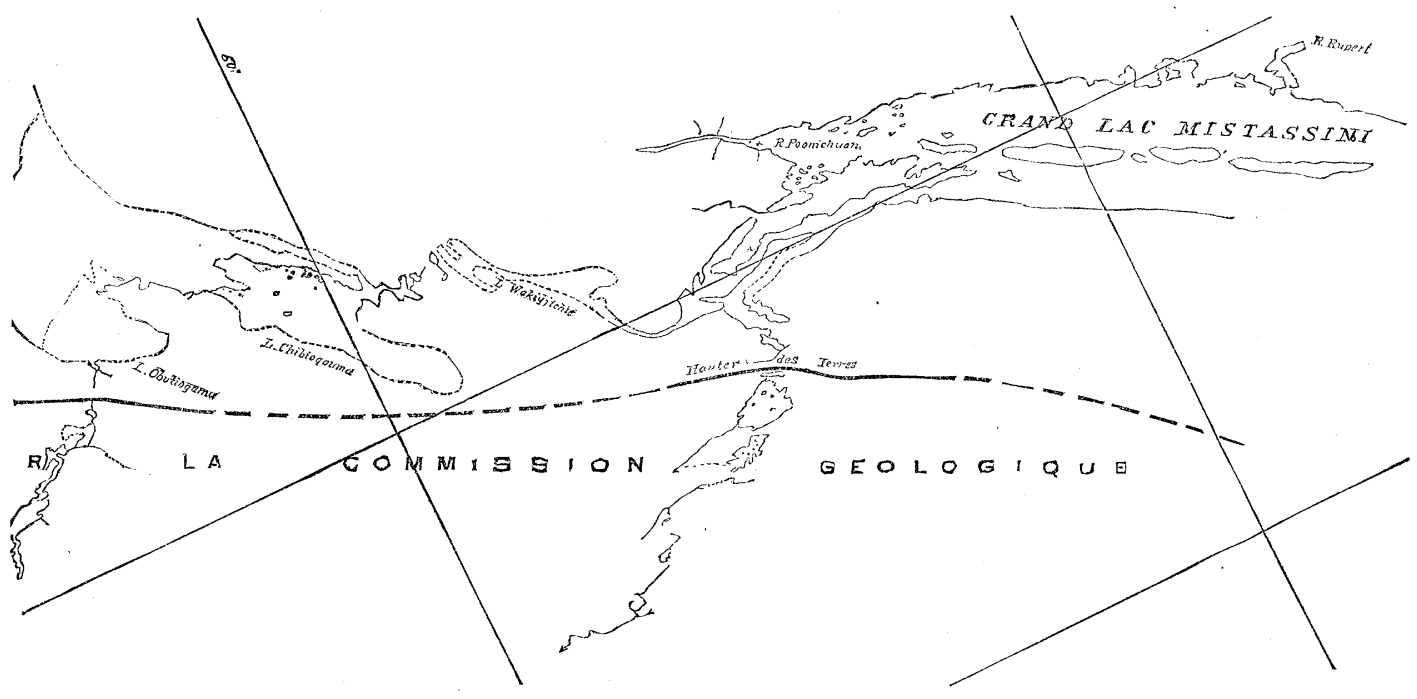

The only published map on which the result of these surveys of 1870 and 1871 by the geological corps is correctly laid down, and which Professor Whitney has probably not seen, is enitled "Carte de la Province de Quebec, Canada. Dressé au département des Terres de la Couronne, par Eugène Taché, assistant commissaire, 1880." The map is on a scale of fourteen miles to one inch; and on the face of it, in the Lake Mistassini region, we find the words 'Exploré par la commission géologique.' This map, and the report I have referred to, give the latest authentic published information about Lake Mistassini. The survey of the lake is, I hope, now in progress; and next year the size of it, and of its numerous arms, will be definitely known from actual measurement. Geolngically it is a basin of flat-lying limestones, probatily of lower Cambrian age, resting on Laurentian and Huronian rocks.

I enclose a tracing of the lake as it appears on the Quebec crown-lands map. The latest general map of Canada is that published in 1882 by the Department of railways and canals, Ottawa. I have not seen the Arrowsmith-Stanford map of 1880 ; but, in the recent maps I have referred to, the position of the lake is nearly half a degree west, not east, of that specimens has verified to the fullest extent the hypotheses made concerning the source of the volcanic sand which fell at Unalashka, Oct. 20, 1883, and the mineralogical composition of the lava from which it originated. The facts noted in Mr. Applegate's letter of information render it altogether probable that the volcanic sand came from the new volcano on Tring Tsland, and a comparison of the sand witl! il is l'm,n that place removes all doubt.

The members of the party from the Corwin sank almost to their knees in soft ashes; and other facts, already published in Science (Nov. 7, p. 432), indicate that a considerable portion of the new mountain may be composed of ejectamenta. It has been stated upon the authority of Lieut. Stoney, I believe, that "the mass of the volcano was found to be a species of sand-rock, with large black rocks scattered about the crust. No traces of lava, and but small quantities of pumice, were found." Whether the 'large black rocks' referred to are portions of lavastreams projecting through the coating of sand and lapilli, or large ejected fragments, is difficult to conjecture. We are led to believe that the specimens received were taken from such masses. Through the courtesy of Mr. Merrill, I have been able to compare 
the specimens sent by Sergeant Applegate with those collected by Lieut. Stoney, and found them to be the same, hornblende andesite.

When we compare the lava from Bogosloff with the volcanic sand which fell at Unalashka, we find them identical in mineralogical composition. Both are composed of triclinic felspar, with prominent zonal structure, augite, hornblende, magnetite, and groundmass, with microlites and a small proportion of amorphous matter.

Dr.T. M. Chatard, of the geological survey, made a partial analysis of the volcanic sand from Unalashka as well as of the lava from Bogosloff. The former contains $52.48 \%$, and the latter $51.65 \%$, of silica. Fearing that an error had been made in the analysis of the lava, Dr. Chatard repeated the determination, and obtained the same result. 'That the perentage of

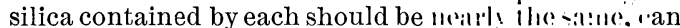
be readily understood; but that the livil shollid (*ontain less than the volcanic sand which is composed of the same material, apparently with a larger proportion of basic minerals, was unexpected. Hornblendeandesite lavas rarely occur with such a low percentage of silica, and in this respect the one from Alaska is closely related to those in the Siebengebirge and Hungary. It is evident that the felspar contained must be very basic, probably anorthite. 'The optical properties of the felspar point in the same direction for the angle of extinction when symmetrical is over $30^{\circ}$. Hypersthene, which is such an important constituent of the lavas in the Cascade Range, has not been discovered in any of the lavas yet examined from Alaska.

U. S. geol. survey, Washington, D.C. J. S. DILLER.

\section{Action of pollen on seed-coats and pericarps.}

I am confounded by a statement, given as if of a well-known fact, which I read in the "Science bulletin' of No. 101. At a meeting of the Academyof natural sciences, Philadelphia, Dec. 16, -

"Mr. Thomas Meehan called attention to an ear of Indian corn received from Mr. Landreth, the grains on one side of which were of a rich brownish-red color, while those on the other side were of the usual pale yellow tint. On the boundary-lines several of the grains were partly red and partly yellow, thus proving that the result was not the effect of crossfertilization, as had been asserted in other instances of change of color. It would indeed be strange if corn were the only plant in which such change of color was produced by cross-fertilization; yet in the case of no other species had any such change been observed."

The sentence I have italicised is the confounding one. It is hard to believe that such a veteran horticultural editor and copious writer as Mr. Meehan is not acquainted at first hand with some of the horticultural literature upon this curious subject (extending from the year 1729 down to our own days), and which asserts that in various instances just such change has been observed. It is harder to believe that a writer who has shown such a critical familiarity with Mr. Darwin's writings should have entirely overlooked a section in chapter xi. of 'Variation under domestication,' vol. i., beginning on p. 397, in which the principal observations (convincing to Darwin's mind as to the facts) are brought together, and the sources referred to. One wonders how the fact that some of the grains of corn were party-colored in the case described, proves 'that the result was not the effect of cross-fertilization,' party-coloration in the flowers being a well-known effect of cross-fertilization, according to good authorities.

\section{THE PEABODY MUSEUM AT NEW HAVEN.}

The Peabody museum in New Haven stands on the corner of Elm and High streets, just without the campus of Yale college. Like most buildings devoted to science in America, it occupies only a part of the large lot, - a fact not designed to typify the unfinished state of zoölogy, but merely resulting from lack of funds. In the present case there would, perhaps, have been no building at all, and the collections, had any of consequence been accumulated at Yale, would have remained stuffed into garrets and cellars, had not the philanthropic George Peabody given a sum of money, in 1866, to erect a house for them. Thanks to the financial prosperity of Massachusetts, the bonds for a hundred and fifty thousand dollars had greatly increased, and those set aside for the first wing of the building had become worth a hundred and seventy-five thousand dollars when the trustees began to build. With that sum they have erected one of the finest buildings, for its purpose, in the United States, a lofty and ornamental structure of red brick and cream-colored stone, whose broad and numerous windows express the desire of the investigators within for all the light they can get.

Let us begin our survey at the bottom. Entering the basement-door, a blind man, or at any rate a blind naturalist (if such there be), would know where he was by that smell of old alcohol with which piologists are so familiar. It is safe to wager, ten to one, that every visitor to these lower regions will remember and quote a certain line from 'The tempest,' act ii. scene 2 .

This pungent odor rises chiefly from the possessions of the U. S. fish-commisšion, deposited for sorting and examination under the eye of Prof. A. E. Verrill, who is chief of the zoölogical part of the museum, or by some of his associates. Duplicates of these submarine and littoral specimens, secured in the government's deep-sea dredgings, go to Professor Verrill, and large quantities deposited by him in the museum have been arranged for exhibition.

In another part of the basement, Prof. O. C. Marsh keeps 'greate store' of fossils, cleaning the gigantic bones from Rocky-Mountain quarries preparatory to study and display. Considerable paleontological property of the U.S. geological survey is under inspection here also. A score of expert helpers, with Oscar Harger as chief of staff, assist; one of whom 